nia, przed jakim stoją nie tylko poszczególne państwa, ale cała wspólnota międzynarodowa. Książka stanowi istotny wkład w dyskusję o charakterze współczesnego terroryzmu, prowadzoną nie tylko w sferze naukowej, ale również w przestrzeni politycznej, wojskowej czy też wywiadowczej. Jej forma oraz czytelny przekaz gwarantują, że na stałe wejdzie do kanonu polskich publikacji poświęconych terroryzmowi.

Jacek RAUBO

Uniwersytet im. Adama Mickiewicza, Poznań

\title{
Edmund J. Hull, High-Value Target. Countering Al Qaeda in Yemen, Potomac Books, Washington 2011, ss. 162.
}

A1-Kaida od samego początku swego istnienia uważała Jemen za strategiczne pole swej aktywności skierowanej nie tylko przeciwko wrogowi wewnętrznemu, ale i zewnętrznemu (a więc świeckiej władzy w tym kraju i współpracujących z nią państw zachodnich - w szczególności Stanów Zjednoczonych). Od początku tzw. wojny z terroryzmem Jemen byl jednym z ważniejszych „frontów” walki z zagrożeniem płynącym ze strony dżihadystów, a precyzyjniej ze strony działających na obszarze tego państwa komórek terrorystycznych Al-Kaidy na Pólwyspie Arabskim.

Analizą tego zagrożenia, a w szczególności analizą amerykańskiego zaangażowania w jego redukcje, zajął się w swej ostatniej książce Edmund J. Hull. W latach 2001-2004 pełnił on funkcję ambasadora USA w Jemenie. Był więc bezpośrednim obserwatorem ewolucji aktywności terrorystycznej Al-Kaidy w powyższym kraju i miał efektywny wpływ na wypracowanie procedur współpracy pomiędzy rządem amerykańskim a władzami jemeńskimi. Znaczącym wkładem ambasadora Hulla jest zwrócenie uwagi na zmianę w strategicznym podejściu do zwalczania zagrożenia dżihadystycznego, która dokonała się na przestrzeni ostatnich kilku lat. Tuż po zamachach z 11 września 2001 r. panowało przekonanie, że efektywnym instrumentarium są narzędzia wojskowe. W kolejnych latach okazało się jednak konieczne bardziej komplementarne spojrzenie na powyższe wyzwanie i połączenie narzędzi wojskowych z politycznymi i ekonomicznymi. Przywołana została w zwiazku z tym słynna i niezmiernie aktualna teza: nie ma bezpieczeństwa bez rozwoju i współpracy (s. XIV).

Recenzowana książka daje także, a może przede wszystkim, wgląd w funkcjonowanie amerykańskiej machiny dyplomatycznej. Wskazuje na powiązania pomiędzy strategicznymi interesami USA na Bliskim W schodzie a dyplomatyczną aktywnością, której głównym celem jest ich realizacja.

Dziesięć rozdziałów pracy ułożonych jest wedle klucza chronologicznego. Ramy czasowe publikacji obejmują okres od 2001 do 2004 r. Cezura początkowa odnosi się do traumatycznych dla Amerykanów wydarzeń związanych z atakami Al-Kaidy na Nowy Jork i Waszyngton. Cezura końcowa ma natomiast związek z zakończeniem misji dyplomatycznej ambasadora Hulla w Jemenie.

W pierwszym rozdziale podjęto próbę przedstawienia narodzin polityki antyterrorystycznej USA w okresie pierwszej kadencji prezydentury George'a W. Busha. Autor trafnie zauważył, że podstawowym mankamentem wypracowanej wówczas strategii było niejasne zdefiniowanie pojęcia „wróg”. Następstwem takiego podejścia (być może zamierzonym) 
było usprawiedliwianie inwazji na Irak walką z zagrożeniem terrorystycznym. Analizując ksztalt relacji pomiędzy różnymi elementami globalnej sieci dżihadystycznej E. J. Hull zapomniał o kilku jej elementach - np. Al-Kaidzie w Islamskim Maghrebie oraz Światowym Froncie Islamskim. Dyskusyjny wydaje się także dobór istotnych czynników, które prowadzić miały do narodzin ideologii ekstremistycznej. Autor pominął aspekt związany z tzw. ruchem odnowy islamu (salafizmem) i walką o zachowanie tożsamości religijnej, skupiając się wyłącznie na czynnikach politycznych i ekonomicznych. Swoboda narracji i przywoływanie szeregu wydarzeń (dotyczących np. narodzin poszczególnych grup zajmujących się walką z terroryzmem) w oparciu o dane pochodzące z pierwszej ręki dają interesujący wgląd w ważne procesy polityczne, które postronnemu obserwatorowi trudno jest uchwycić. Dziwić może np. inercja ważnych organów państwa amerykańskiego zajmujących się problematyką bezpieczeństwa. Ani zamachy terrorystyczne w Kenii i Tanzanii, ani atak na USS Cole nie wpłynęły na podjęcie efektywnych działań na powyższym polu. Przełomowe okazać się miały dopiero zamachy z 11 września $2001 \mathrm{r}$.

Rozdział drugi dotyczy już bezpośrednio Jemenu uznawanego przez Autora za ,bezpieczne schronienie" dla terrorystów z Al-Kaidy. Ambasador Hull podkreśla, że podstawowym celem jego działań w tym kraju było nawiązanie efektywnej współpracy z władzami jemeńskimi w celu eliminacji zagrożenia terrorystycznego. Implikacją takiego podejścia miało stać się oparcie relacji na równoprawnych zasadach. Kolejne lata pokazaly jednak, iż założenia artykułowane jeszcze w pierwszej połowie ubiegłej dekady rozminęły się z praktyką działań kontrterrorystycznych. Kluczową postacią po jemeńskiej stronie w odniesieniu do powyższego wyzwania miał okazać się prezydent Ali Abdullah Saleh, gwarantujacy realizację strategicznych interesów amerykańskich w tym kraju.

W kolejnym, niezmiernie krótkim rozdziale E. J. Hull podjął próbę wythumaczenia, dlaczego Jemen traktowany był przez Amerykanów jako cel aktywności antyterrorystycznej, a nie jako partner w tych działaniach. W kontekście amerykańskiej polityki dotyczącej Bliskiego Wschodu państwo to zajmowało trzeciorzędną pozycję. Politycy amerykańscy nie uświadamiali sobie wówczas najprawdopodobniej skutków ewolucji zagrożenia dżihadystycznego w Jemenie. Świadczą o tym rozważania zawarte w rozdziale czwartym, w którym Autor wskazuje na mankamenty amerykańskich działań antyterrorystycznych (brak wystarczającej liczby agentów operacyjnych, brak rozpoznania środowisk radykalnych, nieefektywne procedury współpracy z władzami jemeńskimi, brak zaangażowania wystarczającej ilości środków materialnych).

Rozdział piąty zawiera w istocie próbę komplementarnego spojrzenia na problemy jemeńskie, w tym i zagrożenie terroryzmem. Główną tezą promowaną przez Autora, która nie doczekała się praktycznej realizacji jest wsparcie działań na rzecz bezpieczeństwa zaangażowaniem USA w rozwój gospodarczy Jemenu. Warte kilkadziesiąt milionów dolarów amerykańskie programy pomocowe pozostają w kontradykcji z wielomiliardowym zaangażowaniem społeczności międzynarodowej widocznym choćby w obietnicach złożonych Jemenowi przez Bank Światowy już w 2002 r.

Wspólpraca antyterrorystyczna, jaką USA i Jemen rozwijały w pierwszej połowie ubiegłej dekady dotyczyła jedynie reakcji na zaistniałe wydarzenia. Egzemplifikacją tego stanu rzeczy jest dla Autora współpraca podjęta po zamachu na francuski tankowiec MV Limburg w dniu 6 października 2002 r. Dotyczyła ona, podobnie jak w odniesieniu do podobnego zamachu sprzed dwóch lat, wspólnego śledztwa mającego doprowadzić do pojmania sprawców. Amerykanie zaniepokojeni najprawdopodobniej nasileniem się podobnych ataków oraz zmianą taktyki działania dżihadystów zaproponowali jednak Jemeńczykom po 
2002 r. zacieśnienie ścisłej współpracy wywiadowczej. Współpracy mało efektywnej zwlaszcza w kilku pierwszych latach. Ambasador Hull nie bada jednak głębiej przyczyn takiego stanu rzeczy.

W kolejnych rozdzialach podejmuje jednak próbę przedstawienia najważniejszych etapów ewolucji powyższej współpracy. Jej waga powiązana byla ze wzrostem znaczenia sieci komórek dżihadystycznych w tym kraju, które przybrały nazwę Al-Kaidy na Pólwyspie Arabskim. Amabsador Hull skupia jednak zbyt dużą uwagę na sprawach z jego punktu widzenia ważnych, ale mniej istotnych dla przebiegu wojny z terroryzmem - np. na zapewnieniu ochrony ambasadzie amerykańskiej w Sanie. Nie można jednak nie zwrócić uwagi na fakt, że bylo to wówczas centrum operacyjnego zarządzania amerykańskimi działaniami antyterrorystycznymi w Jemenie.

W ostatnich dwóch rozdziałach Autor powrócił do rozważań dotyczących dzialań komplementarnych wobec powyższych, a więc do wsparcia rozwoju gospodarczego Jemenu (zwłaszcza prowincji Marib) i zacieśnienia współpracy z USA na takich polach jak nauka czy turystyka.

Ewolucja zagrożenia dżihadystycznego w Jemenie w kolejnych latach uzmysłowila decydentom amerykańskim strategiczne umiejscowienie tego kraju w ramach tzw. wojny $\mathrm{z}$ terroryzmem. Autor pracy wskazal w podsumowaniu na szereg kluczowych wyzwań stojących przed USA w Jemenie w najbliższym czasie. Zaliczył do nich: pojmanie lub likwidację kluczowych przywódców komórek Al-Kaidy na Półwyspie Arabskim, ograniczenie wsparcia dla dżihadystów ze strony lokalnych plemion czy wkroczenie na ścieżkę głębokich reform gospodarczych i politycznych. Ze zrozumiałych powodów wykluczył natomiast trwalą obecność wojsk amerykańskich w Jemenie, które bylyby uznane (tak jak stało się to w Iraku czy Afganistanie) za siły okupacyjne.

Analiza faktograficzna zawarta w poszczególnych rozdziałach pracy wydaje się niestety pobieżna. Autor pominąl lub nie wyartykulowal należycie szeregu kwestii, które mają wpływ na sytuację wewnętrzną Jemenu. O rebelii al-Hothiego wspomniał jedynie w kilku zdaniach w uwagach końcowych. Z drugiej strony warto zauważyć, że E. J. Hull ma jednak świadomość istnienia i wpływu na omawianą problematykę ważnych zmiennych w postaci: czynnika geopolitycznego, etnicznego (w kontekście różnic plemiennych) czy historycznego. Recepcja powiązań między nimi i analiza implikacji dotyczących ewolucji zagrożenia terrorystycznego w tym kraju wymagalyby jednak obszerniejszej analizy. Nie takie bylo jednak zamierzenie Autora.

Lektura recenzowanej publikacji nie sprawi zawodu tym, którzy zainteresowani są analizą ewolucji dzialań amerykańskiej dyplomacji w ramach tzw. wojny z terroryzmem. Pomijany dotychczas teatr działań zostal poddany wreszcie wnikliwej analizie eksperta, którego uwagi pozwalają w istotnym zakresie zrozumieć złożoność wyzwań, z jakimi Amerykanie mają do czynienia w tej części świata. 